\title{
An historical overview of the development of occupational therapy educational institutions in Brazil
}

\author{
Maria Luisa Guillaumon Emmel, Occupational Therapy (Federal University of São Carlos), M Special \\ Education (Federal University of São Carlos), Ph.D. School of Occupational Therapy, Psychology and \\ Human Development (University of São Carlos) \\ Titular Professor, Department of Occupational Therapy - Center of Biological and Health Sciences (CCBS), Federal University of \\ São Carlos (UFSCAR)
}

Daniel Marinho Cezar da Cruz, Occupational Therapy (State University of Pará-Uepa), M. and PhD Special Education (Federal University of São Carlos-UFSCAR)

Adjunct Professor, Department of Occupational Therapy - Center of Biological and Health Sciences (CCBS), Federal University of São Carlos (UFSCAR)

Mirela de Oliveira Figueiredo, Occupational Therapy (Pontifical Catholic University of Campinas), M Child and Adolescent Health, (State University of Campinas), Ph.D. Special Education (Federal University of San Carlos-UFSCAR)

Adjunct Professor, Department of Occupational Therapy - Center of Biological and Health Sciences (CCBS), Federal University of São Carlos (UFSCAR)

Introduction: The first occupational therapy (OT) undergraduate programme in Brazil opened in 1956 in Rio de Janeiro by the "Associação Brasileira Beneficente de Reabilitação", as a technical educational course. It became a university undergraduate programme only in 1969. The aim of this article is to provide a comprehensive overview of the development of OT undergraduate programmes in Brazil. In addition, a mapping of the distribution of existing educational courses in Brazil will be reported through an historical overview. From 1958 until 1986, 15 undergraduate programmes were identified. Between 1987 and 1999, this number increased to 24 and finally between 2000 and 2011 this number was raised to 75 across the whole country. There are some significant differences between the OT courses, depending on the region of the country. The lecturing laboratory spaces that drew the most attention were the Assistive Technology Laboratories, which only began to appear in the middle of the 2000 s.

Conclusion: There was a marked increase throughout the last decade in the number and the quality of OT undergraduate programmes in Brazil, which consequently enhanced the number of occupational therapists in the country, improved standards within the profession and brought advances in the field of practice. In order to understand the role of the practitioners in the contemporary world a dialogue between different countries and continents plays an important role when reflecting on the OT undergraduate programmes.

Keywords: occupational therapy, undergraduate programmes, educational institutions

\section{INTRODUCTION}

Being a relatively new profession in Brazil, Occupational Therapy (OT) has only recently become better known to the general public and has managed to raise its social profile in this country. The first occupational therapy (OT) undergraduate programme in Brazil was opened in 1956 in Rio de Janeiro by the "Associação Brasileira Beneficente de Reabilitação" followed by USP (São Paulo University) a year later, both as practically based technical courses. It became a university undergraduate programme in 1969'.

Recently, decisive developments have been observed within the profession. This is evident not only through the opening of new undergraduate programmes (which allows for an increase in the number of occupational therapists), but also in the expansion of fields within the area. This has seen the development of further research with the implementation of postgraduate studies stricto sensu, such as Masters and Doctorates.
The history of OT in Brazil shows that initially the profession and the subsequent employment of these practitioners into the workplace opened the possibility of new fields of practice that in turn required changes to the profile and role of these specialists and also to their professional education ${ }^{2,3,4}$.

The aim of this article is to describe an overview regarding the development of OT undergraduate programmes in Brazil. A mapping of the distribution of existing educational programmes in Brazil will also be reported through an historical overview.

\section{HISTORICAL OVERVIEW}

During the seventies, the profession did not offer opportunities for practitioners to improve their knowledge effectively, despite programmes relating to methods and techniques that focused on intervention in the traditional areas of the profession such as physical dysfunction and mental health. At the end of that decade, 
the education programmes became full undergraduate university courses and the professional practice was focused mainly on clinical practice. However, the few undergraduate programmes offered in those times were unable to meet the demands of the new positions and fields being created so some practitioners began looking for other ways to improve their professional development.

Occupational therapists began to specialise through courses that emphasised technical instruction. It brought them up to date with the modern world of OT work and provided them with relevant methods and techniques that could be used in the modern workplace. This also satisfied their clinical practice needs, complementing any lack of education in the undergraduate programmes.

At the end of the seventies, this situation started to change as the result of broad changes in public health policies in the country. These changes in the field of health directly involved the practising occupational therapist and acknowledged the need for more comprehensive education within the profession.

During this period, there was an expansion in the concept of health. The understanding of health was evolving, no longer being considered as the simple absence of illness, but instead focusing on the quality of life of the individual and adopting a more humanitarian and preventative approach. Different fields and methods for interventions began to be thought of by occupational therapists and their insertion into multidisciplinary teams became commonly requested, somewhat different to what had been happening up until then ${ }^{3}$.

Parallel to this, the Minimum Curriculum (Currículo Mínimo), for OT undergraduate programmes, was overhauled which instigated a nation-wide re-structuring of these courses in Brazil, especially between 1982 and 1984. The new Minimum Curriculum strengthened the need for specialisation within the profession, requiring more disciplines not only within the traditional core areas of OT, but also in vocational training programmes.

The introduction of more specific disciplines saw an equal distribution of new subjects between biological, psychological and social areas, whilst the majority of new subjects were linked with human sciences and practices involving different levels of health care ${ }^{5}$.

It is remarkable to note that until 1978 there had been only eight OT undergraduate programmes in the whole of Brazil and then between 1979-1986, at least seven more were created ${ }^{6,7}$. Such a situation stimulated the growth of a new field within the profession, which up until then had received little attention: the career of the occupational therapist as a lecturer and academic. This was without doubt another major milestone in the history of OT in Brazil.

This new growth required the development of education for the academics and researchers within the field. Another important aspect to note is that bibliographies used in the undergraduate programmes at that time were completely international. This highlighted the necessity for these academics to start the process of developing knowledge of OT within Brazil, a country which up until then had not had a strong academic tradition within the subject.

At the beginning of the eighties following this development, the universities in Brazil that previously had few occupational therapists on their academic staff began to employ a much larger number of occupational therapists ${ }^{8}$. Those occupational therapists who were lecturing at the universities started to apply for Masters and Doctorates in order to meet the demands of the OT undergraduate programmes.

The lack of postgraduate programmes in Brazil that corresponded directly to the occupational therapists' interests was in contrast to the growing needs for improvements within the profession. The most viable alternative was to look for postgraduate programmes in other fields.

Throughout the 1980s, there was scarce interest amongst occupational therapists for postgraduate studies, such as Masters or Doctorates, as they encountered great difficulties in accessing programmes that were in other fields and whose places were largely restricted to candidates from within those fields ${ }^{3,4}$, such as Special Education, Education, Psychology, Public Health, Social Sciences, and Anthropology.
Apart from the difficulty of enrolling in programmes outside of their field, those who went down this route encountered many other difficulties such as unfamiliar language used in the research (at that time OT undergraduate programmes didn't receive sufficient education in areas outside of their subject).

The Brazilian occupational therapists also faced the challenge of formulating and developing research projects within one field and then having to bridge the gap between the content learned on that programme and the OT, whilst all the time aiming to achieve scientific production in the original area ${ }^{2}$.

Scientific production development emerged with postgraduate studies, together with the possibility of producing knowledge within the field of OT inside Brazil. There is no doubt that the postgraduate study is the route that incorporates the scientific knowledge that can contribute when initiating effective OT interventions. Furthermore, it enables the researcher to experiment, study, research and dedicate time to more thoughtful and reflective activities ${ }^{5}$. Pitout ${ }^{9}$ in her paper investigated research conducted by South African occupational therapists and discussed that the lack of involvement in developing and publishing research constitutes a threat to the OT as a profession, due to the demand for evidence based practice.

Brazilian universities underwent a gradual process of transformation, changing from institutions that basically transmitted knowledge, to becoming institutions that produced knowledge, with the implementation of postgraduate programmes being chiefly responsible for this important transformation ${ }^{10}$.

At the beginning of the nineties, modern society went through a paradigm shift. It went from being an industrial society in which the main frame of reference was the world of work, to being a technical, post-industrial society that wanted a better understanding of Man's function in society. This saw a re-evaluation of other spheres of life, with greater importance being placed on areas outside of work. This search for a better balance between life and work, ultimately leading to a better quality of life, has consequently come to have a strong influence on current thinking of OT.

In addition, the development of new technologies within medicine and rehabilitation broadened the horisons for occupational therapists; this expanded their need for expertise in areas previously not as valued, as is the case, for example, with the use of assistive technology thus generating greater possibilities for adaptations and adjustments. This consequently led to greater independence for people with special needs such as people with disabilities, and the elderly.

However, whilst this accelerated development in society across all fields of knowledge, stimulated by advances in new technology, it brought also a greater dynamism to the world of work and included new illnesses, such as musculoskeletal injuries that currently affect a large number of people throughout the world.

The Brazilian occupational therapist, who previously dealt mainly with people with permanent disabilities, began to be faced with the possibilities of working with people with temporarily reduced functional capacities. With these new situations, the possibility of focusing on preventative treatment, rather than remediation, became a reality. Another change was the increase in life expectancy which greatly increased the percentage of elderly people needing intervention. In turn, we are able to rely on measures or methods that can maintain and preserve functional capacities and skills, or improve the quality of life for these demographics.

The establishment of social policies that provide for the needs of underprivileged sections of the population created another opening field for OTs in Brazil. The occupational therapist was entering these new fields and filling new positions as they were created. They were now being employed as part of health teams, in social and educational institutions and became practitioners that were able to operate in various different capacities. These and many other examples that could be mentioned made up a social OT framework that was completely different to those in previous decades.

New concepts and needs arose within this emerging framework. The occupational therapists closely monitored its developments 
and the evolution so that their profession could quickly answer these new demands as they arose. This required competence, both technological and scientific, and continuous research to keep the individual's knowledge and practices up to date.

The occupational therapist now also worked with people who did not have developmental changes, but instead had temporarily reduced capacities: physical, emotional or intellectual. They were also working with individuals who had become more vulnerable as a result of social exclusion and ruptures in their social networks.

The professional started to act more effectively within their environment too, searching for ways to make it accessible to all. Situations at work were also improved, both physical facilities (environment, equipment, assistive technology) and work relations.

To discuss undergraduate education as a researcher is to also refer to the building and promoting of new knowledge. It supposes the systematic development of ideas, the fruit of contemplative thought and studies that aim to transform an area.

In relation to the target demographic interested in postgraduate studies, it has been verified that occupational therapist researcher's education has become more visible amongst academics. The formative role of educational institutions, creating the need for better educational programmes in lecturing and research, is possibly an important factor in the new demand for researchers.

For this reason, the first national survey of occupational therapist education was conducted in 1996, with a sample of lecturers of OT undergratuation programmes from Brazil. The results pointed to an increase in the number of occupational therapists (lecturers) studying Masters and $\mathrm{PhD}$ programmes in Brazil, especially at public universities ${ }^{3}$.

\section{THE INCREASING NUMBER OF UNDERGRADUATE PROGRAMMES}

Both the number of undergraduate and postgraduate students and the amount of programmes increased. The growth of OT undergraduate programmes in Brazil began with 8 in 1978, 15 in 1986, 24 in 1999, 35 in 2003 and 75 in $2011^{11,12}$.

It can be observed in Table I below that in the last I I years, the number of programmes being offered in the country has increased by $100 \%$.

\section{Table I: Number of OT undergraduate programmes} since 1958

\begin{tabular}{|c|c|c|c|}
\hline Period & $\begin{array}{c}\text { Public } \\
\text { Institutions }\end{array}$ & $\begin{array}{c}\text { Private } \\
\text { Institutions }\end{array}$ & Total \\
\hline $1958-1978$ & 04 & 04 & 08 \\
\hline $1980-1986$ & 01 & 06 & 07 \\
\hline $1996-1999$ & 01 & 08 & 09 \\
\hline $2000-2003$ & 03 & 08 & 11 \\
\hline $2004-2011$ & 11 & 29 & 40 \\
\hline $1958-2011$ & 20 & 55 & 75 \\
\hline
\end{tabular}

With this expansion in the number of undergraduate programmes, the most immediate consequence was a growth in the number of occupational therapists in the country. For example, in 2004, the number of OTs in Brazil was 7025 and in 201 I, the number rose to 13536 occupational therapists in the country ${ }^{13}$. The largest concentration of occupational therapists was in the State of São Paulo, which has approximately one third of these practitioners $(4957)^{14}$. This is explained not so much by the size of that State (with around nineteen million inhabitants) but mainly by its economic, social and cultural position. Therefore, São Paulo is the richest state in the country, with a concentration of income and employment opportunities not seen in any other state in the country.

The greatest number of undergraduate programmes is in the Southeast region which has 43 programmes, followed by the
Northeast, which has 13 programmes and then the South with 9 programmes. The North has 6 programmes and the Middle East there are 4 programmes. The 75 undergraduate programmes in Brazil offer $458 \mathrm{I}$ positions per year, and of these places a much larger number are offered by private educational institutions. Private universities provide 3882 to undergraduate student places of the programmes whereas, public universities only 699'".

\section{PHYSICAL SPACES OF OT UNDERGRADUATE PROGRAMMES IN BRAZIL}

In general, the lecturing laboratories in new undergraduate programmes were very well designed (especially those of private institutions), but conditions were not so satisfactory in some older programmes and in public universities. At the Federal University of São Carlos (Brazil), research groups are composed by professors from the Department of Occupational Therapy (undergraduate) and also from the Occupational Therapy Postgraduate Programme of this university, which now offers both Masters and Doctorates in Occupational Therapy. The professors co-ordinate the research groups that may include undergraduate and postgraduate students (masters and doctorates). Each research group has specific research subjects in different fields of knowledge. All research groups are certified by a Brazilian Federal Research Agency called the National Council of Scientific Researches (CNPq). Research labs were better designed and equipped in the public institutions (Table II on page 66).

Considering the importance of the connection between education and research for undergraduate programmes, some public universities maintain research laboratories. Here the undergraduate is directly involved in scientific initiation programmes with their lecturers, who are Masters and PhD advisors. In general, these programmes have research grants offered by the Brazilian Federal Government.

For example, at the Department of Occupational Therapy in Federal University of São Carlos there are four research laboratories. Their laboratories are: the Laboratory for Activity and Development (LAD), which is concerned with research on human development and human occupations; the Laboratory for Functional Analysis and Assistive Technology (LAFATec); METUIA (a research group related to the studies of Social Occupational Therapy) and the Mental Health Laboratory (LMH). All these laboratories were built according to needs, possessing adequate space and their equipment being maintained through the assistance of research funding bodies.

Man, in balance with himself and his environment, should be the major challenge for this new century ${ }^{12}$. For this, education should be the opportunity for each person to develop his/her intellectual, moral, aesthetic and spiritual capacities. The university is a privileged place that offers far more comprehensive opportunities than simply providing scientific knowledge or a universal culture, creating or advocating knowledge. In this context, the university should prioritise the development of Man who is still a work in progress. This approach needs to be about a dynamic process that avoids stagnation as it seeks to track the changes that are occurring in Man and his environment.

Life at university provides learning and experiences that go far beyond the confines of the department. It gives insights into a universe much larger than just one specific area and allows one to incorporate trends and knowledge that arise in other fields of learning. OT has lived this reality in Brazil, adding to its framework new technologies, methodologies and ways of understanding society that have informed the care practices within the profession and thereby enabled its evolution.

\section{Physical spaces}

The large increase in the number of undergraduate programmes created in the last decade is a result of the new demands of the modern world. Public policies also contributed to this growth. Dur- 
ing the 2000s, the creation of new undergraduate programmes took place primarily in private institutions which equipped their departments well with resources and facilities, especially laboratories for lecturing therapeutic resources (Activities of Daily Living, Assistive

Table II: Description of Laboratories

\begin{tabular}{|c|c|}
\hline LABORATORY & DESCRIPTION \\
\hline $\begin{array}{l}\text { Craft Resources } \\
\text { and Manual Arts }\end{array}$ & $\begin{array}{l}\text { These types of laboratories existed on all the } \\
\text { undergraduate programmes and are generally } \\
\text { for the exclusive use of the OT departments. }\end{array}$ \\
\hline $\begin{array}{l}\text { Physical } \\
\text { Activities }\end{array}$ & $\begin{array}{l}\text { These spaces are usually scheduled for lessons } \\
\text { that involved physical and therapeutic resources } \\
\text { and psychomotricity. }\end{array}$ \\
\hline $\begin{array}{l}\text { Activity of Daily } \\
\text { Living - ADL }\end{array}$ & $\begin{array}{l}\text { In recent years, undergraduate programmes in } \\
\text { OT have devoted more individual attention to } \\
\text { this kind of lab. Since } 2000, \text { ADL lab spaces have } \\
\text { begun to be seen on almost all undergraduate } \\
\text { programmes. Often taking the form of a house, } \\
\text { there are also laboratories where spaces are } \\
\text { adapted and creatively arranged in the shape } \\
\text { of an amphitheater. Between } 2003 \text { and } 2005 \text { it } \\
\text { was common for this space to be shared with } \\
\text { the laboratory for Prosthetics, Orthotics and } \\
\text { Assistive Technology, which also began to appear } \\
\text { as a structured laboratory on undergraduate } \\
\text { programmes. }\end{array}$ \\
\hline $\begin{array}{l}\text { Assistive } \\
\text { Technology }\end{array}$ & $\begin{array}{l}\text { In } 2004 \text { these laboratories were still infrequent } \\
\text { and poorly equipped. In general, a laboratory } \\
\text { was limited to being a small room containing } \\
\text { a few wheelchairs and some adapted } \\
\text { materials, and was visibly a new acquisition. } \\
\text { Such laboratories are currently acquiring } \\
\text { technological innovations and resources } \\
\text { to support practical classes. This space is } \\
\text { still commonly shared with Prosthetics and } \\
\text { Orthotics. }\end{array}$ \\
\hline
\end{tabular}

\begin{tabular}{|l|l|}
\hline Kinesiology & In the majority of cases, Kinesiology laboratories
\end{tabular} are shared with Physiotherapy undergraduate programmes, with the laboratories frequently being owned by the Physiotherapy undergraduate programme and loaned to the OT programme.

\begin{tabular}{l|l} 
Community & The structure of these programmes, in general,
\end{tabular} Assistance $\quad$ involves a clinical school unit for the practical activities of students and services for the local and regional community, combining lecturing with community outreach projects. Although the physical spaces of these laboratories is showing significant progress, with spaces designed specifically for this purpose, the same quality in equipment is not yet seen on all programmes and the vast majorities are below the desired modern levels.

Another alternative widely used by institutions is offering practical activities through services that already exist within the community (schools, clinics, hospitals, businesses, etc.). In 2011 this situation began to change with multidisciplinary clinical schools and with better resources for care.

Research
Technology, Physical and Expressive Activities, etc.) ${ }^{12}$.

In the mid-2000s, the Brazilian federal government created a series of programmes to encourage the expansion of higher education in Brazil. They built new federal universities in regions where before there had been little opportunity for higher education whilst increasing the number of places in those that already existed. These initiatives contributed to an increase in OT undergraduate programmes in the country funded by the government. Despite all these efforts, there remains a concentration of universities in the Southeast, because of the established conditions of wealth, culture and the presence of skilled human resources working in higher education.

Out of the laboratories used for teaching (such as the traditional ones eg activities of daily living, physical and expressive activities and kinesiology), the one that drew attention was the assistive technology laboratory, which only began to appear in the middle of the first decade of the 2000s. In spite of this, the education in this area in the undergraduate programmes still appears to remain poor.

At the end of the 2000 s, encouraged by policies of inclusion, technological advances and through the advantages that became available with imports enabled by the arrival of the internet, this area showed significant growth and its lecturing laboratories reflect these developments, both in the materials and equipment used and also in the content of its related disciplines ${ }^{15}$.

Such considerations also apply to research laboratories in general, where the researchers working in this area are encouraging the modernisation of the laboratories. This has produced very promising signs in the development of those students who incorporate the exercise of research in their academic careers, something that is not always possible during normal curricular activities.

Until 20I0, there was no specific OT postgraduate programme in Brazil or even in Latin America, which explains why all occupational therapists up until then did their research in postgraduate programmes in other fields of knowledge. The recent implementation of postgraduate programmes specific to OT in Brazil has begun to answer the need for knowledge production at a national level that was first noted in the eighties. The first postgraduate programme in Brazil for OT was created in 2010, namely Postgraduate Occupational Therapy Course (PPGTO) by the Federa University of São Carlos, São Carlos, São Paulo' ${ }^{16}$. Such evolution from the undergraduate to postgraduate is based on the belief that all occupational therapists might have an important role in research to contribute to the best evidence based practice ${ }^{17}$.

Regarding lecturers' offices, there should be a prioritisation of space that enables activities which allow concentration and focus for the occupants, allowing them to dedicate themselves to their studies, prepare lessons and also to supervise their students. Generally, in private institutions, the offices are areas shared by all of the lecturers. These are places for meeting and talking or just passing through, lacking private offices in which the lecturers can devote themselves to more contemplative and concentrated activities ${ }^{12}$. Those in the public institutions are more private, with offices for one to three lecturers and are, therefore, more suitable for their purpose.

When there are shared office spaces, activities with students can be disrupted. Either the activities with the students are impaired, the lecturer disrupts his colleague, or the lecturer must leave his office to continue the activity elsewhere.

\section{RECOMMENDATIONS AND CONCLUSION}

This commentary has shown that there was a marked increase throughout the last decade in the number and the quality of OT educational programmes in Brazil, which consequently increased the numbers of occupational therapists in the country, improved standards within the profession and brought advances in the field of practice.

The growing number of practitioners entering into increasingly larger areas of work has given greater social legitimacy to the pro- 
fession, which is now much more highly regarded by the Brazilian population. There is no doubt that a national presence and influence, even if it is still growing, is beneficial for the dissemination of the profession.

This description paper gathered information about the distribution of undergraduate programmes in the country and showed their impressive increasing numbers.

Regarding lecturing laboratories and research, there are striking differences depending more or less on the structure of the undergraduate programmes.

Following on from this, a diagnosis of the situation in higher education institutes also implies identifying the paths and processes that have led to the development of a new professional profile for the occupational therapist. This is a crucial moment in the history of OT in Brazil, marked by a territorial expansion in the number of undergraduate programmes and also with the first postgraduate course.

The advances made in the last decade with respect to institutions that offer undergraduate programmes in OT must be recognised and celebrated. The diversity within the present situation, with differences in the type of institution, region of the country, levels of productivity and opportunities for postgraduate education is a source for reflection and consideration that could help each undergraduate programme to forge its own path thus creating effective approaches for the implementation of measures that promote occupational therapist education throughout the whole of Brazil and not just in privileged regions.

Modern society needs to bring the needs for new skills and education. It is not only undergraduate programmes that need to be attentive to the new demands of society, but also academics, who must constantly revise and update their knowledge and ensure that they are able to meet the needs of this "new society".

For recommendations, we agree with Galheigo ${ }^{18}$ who accurately states in her article entitled "What needs to be done? Occupational therapy responsibilities and challenges regarding human rights", based on her experiences from South Africa, Brazil and Chile, where she discusses the importance of across the board dialogue of occupational therapists: "Occupational therapy will celebrate its first century as a profession. In the complex societies we live in today, there is a call for interconnectedness, which is operated through networks and a cross-bordering dialogue"18:65.

Thus, we believe the major challenges for Brazilian OT today is to establish itself in a position from where it can contribute to the great transformations of the contemporary world, whilst at the same time constantly revising and updating its practices to enable it to pre-empt the needs, predict solutions and meet the new demands of global world society.

\section{ACKNOWLEDGEMENTS}

To Julie Clare Tidd and Lee Anthony Ward for reviewing the original of this article.

This study received grants from FAPESP (Fundaçãode de Amparo a Pesquiso do Estado de São Paulo).

\section{REFERENCES}

I. Soares LBT. Terapia Ocupacional: lógica do capital ou do trabalho? São Paulo: Hucitec.

2. Emmel MLG, Lancman S. Quem são nossos mestres e doutores ? O avanço da capacitação docente em Terapia Ocupacional no Brasil. Cadernos de Terapia Ocupacional da UFSCar, 1998; 7(I): 29-38.

3. Emmel MLG, Lancman S. La recherche en ergothérapie: développement de la formation des enseignants au brésil. Canadian Journal of Occupational Therapy, 2003; 70: 97-100.

4. Barros DD, Oliver F. Contribuindo para a discussão do Qualis de terapia ocupacional no Brasil. Rev. Ter. Ocup. Univ. São Paulo, 2003; I4(2): 52-63.

5. Emmel MLG. Atuação da Terapia Ocupacional no processo de inclusão social: Implicações da Formação na Prática Profissional. In: Marquezine MC, et al. (Orgs.). Inclusão. Londrina: Editora da
Universidade de Londrina; 2003. p.295-309.

6. Toyoda CY, Pinto JM, Emmel MLG. Evolução científica da Terapia Ocupacional no Brasil (1984-1986). Relatório CNPq, São Carlos: UFSCar, 1986.

7. Toyoda CY, Pinto JM, Soares LBT, Emmel MLG. Programa Básico de Terapia Ocupacional. São Carlos: CNPq, 1988.

8. Ferrigno ISV. Um estudo sobre os docentes de terapia ocupacional como agentes transformadores da profissão. Dissertação Mestrado. São Paulo: Pontifícia Universidade Católica de São Paulo, 1990.

9. Pitout $\mathrm{H}$. Barriers and strategies to increase research involvement of South African occupational therapists. South African Journal of Occupational Therapy, 2014; 44(2): 17-21.

10. Spagnolo FE, Günter H. 20 Anos de pós-graduação: o que fazem nossos mestres e doutores? Uma visão geral. Ciência e Cultura, 1996; 38(10): 1643-1662.

II. MEC. Ministério da Educação e Cultura. Instituições de Educação Superior e Cursos Cadastrados. Disponível em: http://emec.mec. gov.brl. Acesso em 20/12/20II.

12. Emmel MLG. Caracterização dos cursos de terapia ocupacional do Brasil: perspectivas frente à capacitação docente. Relatório de Pesquisa, São Paulo: FAPESP, 2005.

13. COFFITO. Conselho Federal de Fisioterapia e Terapia Ocupacional. Perguntas mais frequentes. Quantitativo de profissionais. Disponível em: http://www.coffito.org.br. Acesso em 18/0I/20I2.

14. CREFITO 3. Conselho Regional de fisioterapia e Terapia Ocupacional. 3 Região. Pesquisa de inscritos. Estatistica de Profissionais. Disponível em: http://www.crefito3.org/br/dsn/app site/webgovpes.htm

15. Marins SCF. Design universal, acessibilidade e tecnologia assistiva: a formação profissional do terapeuta ocupacional na perspectiva da equidade. Tese Doutorado. São Carlos: Programa de Pós Graduação em Educação Especial, Universidade Federal de São Carlos, 201 I .

16. Malfitano APS, Matsukura TS, Martinez CMS, Emmel MLG, Lopes RE. Programa de pós-graduação stricto sensu em terapia ocupacional: fortalecimento e expansão da produção de conhecimento na área. Revista Brasileira de Atividade Física e Saúde, 2013; 18 : 105-III.

17. Pitout H. Research Orientation of South African occupational therapists. South African Journal of Occupational Therapy, 2014; 43(2):5-II.

18. Galheigo SM. What needs to be done? Occupational therapy responsibilities and challenges regarding human rights. Australian Occupational Therapy Journal, 20I I; 58, 60-66.

Corresponding Author

Daniel Marinho Cruz

Rodovia Washington Luís,

km 235 - SP-3 10, São Carlos,

São Paulo, CEP I3565-905

cruzdmc@gmail.com 